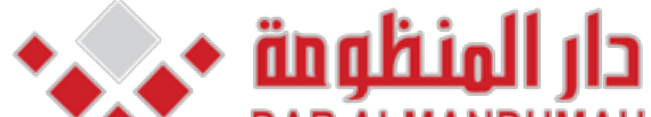 DAR ALMANDUMAH

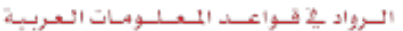

The Religious Conseciousness of Egyptian People seen through the Lyrics of Traditional Folk Song

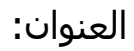
مجلة كلية اللغات والترجمة

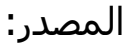
جامعة الازهر - كلية اللغات والترجمة

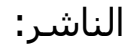

Kyeong, Yun Eun $4 \varepsilon$

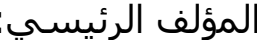
نعم

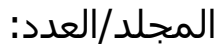
نمa

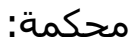

2013

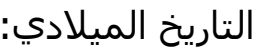
يناير

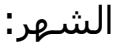

$5-27$

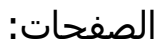

761736

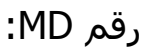

بحوث ومقالات

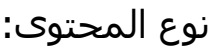

AraBase

الوعي الديني ، الأغنيات الشعبية ، الشعب المصري

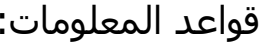
http://search.mandumah.com/Record/761736

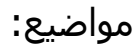
رابط: 


\title{
The Religious Consciousness of Egyptian People seen through the Lyrics of Traditional Folk Song
}

\author{
By
}

Yun, Eun Kyeong (HUFS, SeouL, South Korea) ${ }^{(1)}$

(1)Research Professor in the Department of Arabic Language, HUFS 


\section{Abstract}

The songs of a country represent its people's lives and culture. The lyrics of the songs reflect the various aspects of people's lives living in a certain era. Generally, as the people's song, popular music paints a portrait of the public's enjoyment of culture and part of the socio-culture. This study aims to illustrate characteristics of Egyptian folk songs and examine the religious consciousness of the Egyptian people seen through lyrics by classifying motifs of Egyptian songs. The Egyptian's way of thinking in steering closer to Allah can be seen through religious motifs such as the authority and Providence of the Almighty God, man's absolute obedience to God, appraisal of the prophets and saints, Islamic fatalism, and Islamic duty of pilgrimage and prayer.

Since the $7^{\text {th }}$ centuiy, Islam has occupied the central of the Middle East civilization, impacting the Egyptian's way of thinking and structural development of common people. And it can be said that to this day forward, it still comprises an insurmountable portion of the popular culture thereby providing understanding of sacredness. The firm belief in the One and only God, a believer's ideal virtues, compliance to Islamic doctrine, and such are established in the Arab people's way of thinking as the element of holiness. The way of thinking about sacredness implied in the Egyptian songs emphasize the Islamic doctrine and absolute obedience to the Almighty God, keeping the faith in the Prophet, goodness and virtue in a personal relationship, and the importance of faith.

[Key words: Egyptian Song, Lyrics, Islam, Religious Consciousness] 


\section{Introduction}

The songs of a country represent its people's lives and culture. The lyrics of the songs reflect the various aspects of people's lives living in a certain era. Generally, as the people's song, popular music paints a portrait of the public's enjoyment of culture and part of the socio-culture. Through popular music, the whole of the socio-culture can be understood. The lyrics of popular music are combined with melody to express the thoughts and feelings of the - populace. The lives, emotions, and the social aspects of people living in the same era are directly or indirectly embedded in the lyrics of popular music. As the form of music changes according to the needs of the common people of a society, the song texts of the music contain the lives and the rituals of the common people of that era. Thus, it can be implied that cultural phenomena, social aspects, and the way of thinking of the common people can be interpreted through the study of the text of songs.

In order to understand the culture and customs of the members of a certain society, the social class - upper, middle, lower class- in which the people belong to must first be observed. Moreover, in order to comprehend the universal culture of the society, it is important to appreciate the culture of the lower class commoners, who constitute the majority of the populace. This is because the general public has carried on the role of maintaining the history and the culture of the local area. As it would be impossible to comprehend the real aspect of a society or nation without the fall understanding of the general public's emotion and way of thinking, understanding the underlying culture has taken an important part in the research of overseas regional studies.

This paper will mainly focus on Egypt among die many Arab countries. First, the paper will introduce Egyptian folk songs and then closely examine the lyrics of the songs with the representation of the expressions of sacredness in the Egyptian traditional folk song and categorize them according to the themes 
and examine the religious consciousness of Egyptian people based on these themes.

\section{An Overview of the Egyptian Songs}

Egyptian music is thought to have originated during the reign of the pharaohs. Images of ancient Egyptians playing the harp, flute and other instruments of that era vividly remain in murals. However, the development of musical notation at that time was not developed and therefore songs that were widely sung by the people were not documented. After the 7th century AD, Arabs from the Arabian Peninsula came into Egypt and neighboring regions of northern Africa. Since then, traditional Arab music established during the Syrian Umayyad period was introduced into Egypt. The Arabic music introduced into Egypt developed through an evolvement with the indigenous folk music of Egypt.

The domain of popular and folk music often provides insight into the psychological and temperamental traits of a nation's character. By studying the types of songs, the styles, music related social occasions and musical traditions one can often illustrate the spirit and beliefs of the nation. The general characteristics of popular forms of art can be found in Egyptian folk songs. Such traits are as the absence of specialized and tutored professional musicians or singers, the absence of an aristocratic and paying audience, ignorance of abstract theories on the technique employed and the dependence on oral tradition, transmits many folk music characteristics. Egyptian folk song exhibiting such traits existed in the Islamic culture and was sung and played by the people. This is quite distinct from the artistic and higher form of music that evolved under the auspices of the courts and wealthy aristocracy. The functions of folk music may be divided into two main divisions. The first division usually refers to music attached to social occasions, which covers such celebrations whether of rejoicing or of mourning. The second division comprises songs of 
labor such as caravans-songs and shepherd's tunes. Music covers a wide field in the everyday life of the Egyptian society. Egyptian songs can be classified into the following - Egyptian traditional folk song Mawwāl, work song, religious music, contemporary popular music and so on.

\subsection{Mawwāl}

Mawwāl is not only a creative art form of the Arab people but also the subject of interest of many scholars as a type of music with a touch of tune. Scholars agree that Mawwāl is a widely recognized popular art song not only in Egypt but also in other Arab countries; however, their opinions on the origin of Mawwāl differ.

Some scholars suggest that Mawwāl began with the slaves who used to chant the words "Ah, Mawwāli, Mawwāli" as a chorus while working (Safa alDin al-hali, 1960: 14). Others claim that the term Mawwāl itself is part of the Muwalah rhyme that it maintains or because somebody cried out 'Ah, Mawwāli' repeatedly while mourning. Others believe the term originated from Mawwāli bn Barmak, the fust person to use the term ('Ahmad Mursi, 1970: 6667). Even though there are diverse opinions as to the origin of the term Mawwāl, a firm theory that can logically justify the origin or the name of Mawwāl has not yet been verified. In fact, the term 'Mawwāl' appears not only in the Egyptian people's songs but also in many Arab people's songs. According to Muhammad Bu Dinah, Mawwāl is divided into three major categories ('Ahmad Mursi, 1970:29, Muhammad Bu Dinah, 1999:13-15).

The first one is a fixed form, meaning the form itself does not change and the meaning is completed in its form. For example, the Baghdad Mawwāl, also known as the 4 line Mawwāl (al-Mawwāl al-rubā' $\mathfrak{j}$ ), is characterized by a rhyme which consists of 4 uniform lines. The second one is the incomplete Mawwāl (al-Mawwāl al-'a 'raj)' or the '5 line Mawwāl (al- Mawwāl alkhumāsi)'. It consists of 5 lines, the rhymes of the first three lines have a 
concurring form as the rhymes of the last or fifth line. The rhyme of the fourth line differs from. the rest.

This form was used when the Mawali lyricist felt that the well-known 4 line Mawwāl framework was insufficient to express their meaning, and introduced a new line with a. different rhyme between the third and fourth line ('Ahmad Mursi, 1960: 29).The third one which consists of 7 lines is known as 'al-Mawwāl al-Nu'mani' or the 7 line Mawwāl (al- Mawwāl al-subā'i). This form is characterized by the first, second, third, and the seventh lines taking on a uniform rhyme, while the fourth, fifth, and sixth lines take on a rhyme different from the others. The Nu'man Mawwāl is best known form among professional folk singers, especially in Egyptian public society, and the story telling Mawwāl (al-Mawwāl al-qiș̣ași) takes this form. These three types are the most widely known in the Arab world.

\subsection{Work Song}

The terms folk music, folk song are comparatively recent expressions. They are extensions of the term folk lore, which was coined in 1846 by the English antiquarian William Toms describe "the traditions, customs, and superstitions of the uncultured classes." The term is further derived from the German expression Volk, in the sense of "the people as a whole" as applied to popular and national music by Johann G. Herder and the German Romantics over half a century earlier. Traditional folk music also includes most indigenous music. However, despite the assembly of an enormous body of work over some two centuries, there is still no certain definition of what folk music (or folklore, or the folk) is. Folk music may tend to have certain characteristics but it cannot clearly be differentiated in purely musical terms. One meaning often given is that of "old songs, with no known composers", another is that of music that has been submitted to an evolutionary process of oral transmission, the fashioning and re- fashioning of the music by the community that give it its folk character. 
Such definitions depend upon cultural processes rather than abstract musical types, upon continuity and oral transmission...seen as characterizing one side of a cultural dichotomy, the other side of which is found not only in the lower layers of feudal, capitalist and some oriental societies but also in primitive societies and in parts of popular cultures. One widely used definition is simply "Folk music is what the people sing". From a historical perspective, traditional folk music had these characteristics. It was transmitted through an oral tradition. The music was often related to national culture. It was culturally particular; from a particular region or culture. A work song is a piece of traditional folk music closely connected to a specific form of work, either sung while conducting a task or a song linked to a task or trade which might be a connected narrative description, or protest song. Records of work songs are roughly as old as historical records, and anthropological evidence suggests that all agrarian societies tend to have them. Most modem commentators on work songs have included both songs sung while working as well as songs about work, since the two categories are seen as interconnected.

\subsection{Religious Music}

The relationship between music and religion is so profound that all religions around the world have each developed its own religious music with various forms and types. The fact that music consists of notes is similar to a religious experience because music evokes emotions past logical sense. In the case of Islam, the doctrinal use of music in worship is sometimes excluded because it is believed that music evokes sensual pleasures. However, regardless of doctrine, during the recitation of the Koran or the telling of the worship time (adhān), music is used.

Religious music in the Arab world includes mosque music, Sufi music (şufi, Islamic mysticism), conventional religious music etc. A unique rhythm that appears during the recitation of the Islamic Koran and Azan (adhān, 
worship or cry) in the music can be heard in the mosque. The Azan rhythm consists of a standardized system like the Koran recitation that it does not vary across the Islamic regions. Sufi music is used for the purpose to inspire faith in God and consists of its own unique rhythmical structure. Differences in Sufi music occur regionally according to indigenous religious beliefs and use a combination of traditional Islamic elements.

Conventional religious music, which refers to the texts lauding Islamic religion and adults, differ regionally due to a mixture of written and colloquial Arabic used in lyrics and songs. Also, religious music of Egyptian society has a wide variety; however, this study will examine music sung by the common people during various religious ceremonies.

Egyptian religious music is closely related to various religious ceremonies or events, holidays, and festivals celebrated by the common people. One of the important religious events for Egyptians includes the prophet's birthday or the pilgrimage. The religious songs sung during these celebrations deal with Islamic doctrine and contents relating to religious faith and therefore are characterized as having a pious and sacred ambience compared to other songs. Motifs of religious music are mainly religious stories, God's omniscience and omnipotence, information revealed in the Koran that are retold to the public or contain information about the miracles performed by the prophets or saints.

\subsection{Contemporary Music}

The history of Egyptian contemporary music started in 1910 by Sayyd Darwish. He incorporated Western music with Egypt's traditional music, creating his own unique music world which he imparted to the future generations (Kamal al-Nāji, 1992:193-194). He listened to various types of music from other countries, especially music from the Greek and Italian regions, and further developed Egyptian contemporary music. One of his contributions includes using the $3 / 4$ note or a new form of music using the whole 
or half note. Muhammad 'Abd al-Wahāb and Umm Kulthūm, the female singer also known as the 'Star of the East', along with Amr Diyāb, 'Ihāb Tawfiq, and Zakariya 'Ahmad, who are active today, are some of Egypt's most famous singers. Muhammad 'Abd al- Wahāb, a prominent figure known to have further developed Egyptian music, advanced Egyptian music using the unique colloquial Egyptian dialect, which in turn influenced the music of the Gulf regioa Both the Gulf region and Siam region showed interest in Egyptian music and they began to be widely sung in those areas. Among them, a song composed by Sayyd Darwish and sung by Umm Kulthūm captured the public's heart This catapulted her career and she was recognized as an influential singer in the Arab world. Having influenced the music of the Siam region, Umm Kulthūm and her songs were loved by many and such singers like Fayrūz and others were influenced by her. Today, Amr Diyāb's songs have been widely introduced and sung not only in the Arab world but also in the Western world as well. A Mixture of traditional Arabic rhythm and Western contemporary music, his songs, which incorporate a new music style, have become popular among the young Arab people. In his songs, the lyrics with themes that can be dealt lightly, such as everyday life and sex, are predominant instead of long and classical Qasida.

\section{The religious consciousness seen through the lyrics}

\subsection{God's omnipotence, appraisal of the prophets and saints}

The Koran is considered the base in Islamic and Arabic countries. The core beliefs of Islam are that there is only one god -unitary and beyond comprehension - and that Muhammad is the prophet of God, The Qur'an is upheld as the eternal, literal word of God, and revelations to earlier prophets are believed to have become distorted by human intervention. Muslims believe that the Koran was revealed to Muhammad through the angel Gabriel, and belief in angels as God's servants is part of the Islamic tradition. Since Arabic 
music was heavily influenced by religion, sometimes verses taken from the Koran are sung as it is or to express belief, faith, or awe towards Allah. The Islamic religion has had a profound impact on Arabic music overall, and religious factors appear in all musical expression Lyrics rooted from religion can also be found, such as calling out, 'Allah', 'O Lord' asking for redemption.

Motifs related to religion in Egyptian song lyrics involve saints, God, the prophet Mohammed, Imam and such that provide insight to the Almighty God's power and providence, man's absolute obedience to God, appraisal of the prophets and saints, the insights of the prophets and saints, unerring accuracy of the saints and Imam, sacredness and such.

"kullu māyashdu maḥamel... linnabi qalbi yehim... kullu māyashdu maḥamel... linnabi qalbi yehim... la sa'iy we 'azur annaby we 'army ḥmuly 'aleh we 'in haṣalak daym nade yā'imām 'ali..."

(All that he sang... has been ladea.. /the prophet..

to take my heart into interest...

All that he sang... .has been laden... /the prophet...

to take my heart into interest...

It doesn't matter.. .I'll visit the prophet and throw my load to him... and if you were insulted.. .let's call.. .Oh Imam ' Ali...)"

The lyrics above are part of a song sung by Egyptian fishermen, while fishing in groups, in the northern lakes of the Nile delta - Manzala and Borullus ('Ahmad Mursi. 1970:81). This tune is repeated continuously and the fishermen move on to other tunes in this manner until the work is finished. A religious motif, the mentality of the fishermen expecting a full load of fish through the prophet's generosity, can be read in the lyrics. Like the first half of the song, religious motifs that express the fishermen's dependency on the prophet and 
Ali Imam for more fish to be caught occur repeatedly in the latter part of this song.

Religious motifs such as the appraisal of the apostles and saints, the insights of the saints and prophets, unerring accuracy of the saints and Imam, sacredness, and such appear thoroughly in songs.

"wallāhi in țala zamani la shaki legādi elghram liashki legādi elghram... liashki legādi elghram 'eshg elbanāt ya gādi ḥarām we 'ille ḥallāl ḥarām we 'ille ḥallāl... ḥarām we 'ille ḥallāl ḥarām lilmtazawj 'ama 'azeb ḥallāl 'ama'azeb ḥallāl

: we 'in kāna ḥaiām ya qādi 'uktub li bil ḥallāl 'uktub li bil ḥallāl... 'uktub li bil hallāl karāmah li nnabi...: karāmah li nnabi...

bișṣalāh 'ala nabi... bișșalāh 'ala nabi...

ghafer min gher maheh'alashān ḥub gamil

'alashān ḥub gamil

karāmah li nnabi karāmah li nnabi

we ya bint ya malayah...

'umdat baladikum mia..'umdat baladikum min... karāmah li nnabi... karāmah li nnabi 'umdat baladinaalra'is tājir lmnedil...tājir lmnedil karāmah li nnabi... karāmah li nnabi..."

(If time is delayed, I will appeal to the judges...

Judge... is it Haram or Halal to love a girl.../

to a married man, it is Haram...

to a bachelor, it is Halal...to a bachelor, it is Halal...

Judge...even if it is considered Haram...

Write it as Halal... Halal...

respect to the prophet... pray to the prophet.. 
Forgiveness... for the beautiful love ...for the beautiful love... respect to the prophet... respect to the prophet... water mowing girl... who is village chief...who is village chief... respect to the prophet... respect to the prophet...

Our village chief is towel longevity... towel longevity respect to the prophet... respect to the prophet...)"

The song above, asking a judge whether it is a sinful or not to love a woman, contains a rather comical element The fact that it is forbidden for a married man to love a woman other than his wife but for a bachelor it is allowed shows Egyptians 'ritual of faithfully following the Islamic doctrine. In addition, the Egyptian's consciousness of religion can be seen through the lyrics of the song which says that even though love is forbidden, it should be ruled as Halal and is pleading for tolerance that it be allowed.

Meanwhile, there are cases in which the verses in the Koran are directly cited in Egyptian songs.

"yārabb yākhāliq al-khalq.. yārabb al-'ibād/ wa man qad qult fl 1-qurān 'ud'ūni innani da'awtuka mudțaran fa khud biyadi/

yājāmi al'amr bayna al-kāf wa annūn...

najit 'ayyub min buluwahu hīna da'ā... innani da'awtuka mudţaran fa khud biyadi...

(O Lord... O Creator of the truth...Lord of prayer...

/You said the words in the Koran... pray to me...

I did pray to you truly... Take my hand.../ 
Oh... Lord ...who has connected the matter between al-kāf and al-nūn... You saved the prophet Ayyub when he prayed...

I did pray to you truly... Take my hand...)"

In the song above, the lyric itself takes on a prayer format in order for both the singers and listeners to devote themselves to Allah. As his illness was cured by Allah, the prophet Ayyub tells the citizens that they should pray to Allah and ask for salvation, and this takes on a story format about heaven and hell, sin and punishment, etc. Stories such as what a man has to do to in order to find the way to heaven and to avoid the punishment of the burning pits of hell are expressed in the songs. Praying while faithfully carrying out one's duty as a Muslim is emphasized as the only way to becoming closer to Allah.

"yā'ạ̣san al- 'abd lamāyakunu sālik

wa kulu bāb yadkhuluhu yujaduhu sālik...

qalili tam'uka wa ruhi 'abki 'alāhālika ridwān yaqulu linnabi 'udkhul al jannah haniyan laka rawi al bukhari wa muslim wa l-'imam malika katra al salāh 'ala nnabi... tamna“" 'edhab mālika..."

(The greatest slave.... that path shall be smooth...

the door in whichever you enter will be smooth....

Reduce your greediness.. .for my soul cries at your situation...

Ridwan, the angel of heaven, speaks to you...

Go into heavea...pray much to the Prophet...

Ban the punishment of Malika, the angel of hell...)"

The religious belief of the Egyptian in Ridwan, the angel of heaven, and Malika, the angel of hell, which appear in the Koran can be seen through the song mentioned above. Also, faith in the Islamic doctrine, that only when one 
has prayed to the Prophet and reduced one's greed can one get to heaven, appears as the main motif.

\subsection{Religious rituals}

Among Egyptian songs, there are songs which are related to religious rituals. These songs are sung when departing on a pilgrimage to the Holy Land (Al-hajj). The pilgrimage is a religious ritual not only performed by the Egyptians but the Arabs as well. Worship songs about the pilgrimage, one of the five duties of the religion of Islam, or the holy rituals of Muslims appear frequently in songs.

There are some characteristics that describe songs that are about the pilgrimage. A pilgrimage is a journey or search of moral or spiritual significance. Typically, it is a journey to a shrine or other location of importance to a person's beliefs and faith, although sometimes it can be a metaphorical journey in to someone's own beliefs. Many religions attach spiritual importance to particular places: the place of birth or death of founders or saints, or to the place of their calling or spiritual awakening, or of their connection with the divine, or to locations where miracles were performed or witnessed, or locations where a deity is said to live or be housed, or any site that is seen to have special spiritual powers. Such sites may be commemorated with shrines or temples that devotees are encouraged to visit for their own spiritual benefit: to be healed or have questions answered or to achieve some other spiritual benefit A person who makes such a journey is called a pilgrim. If we examine the lyrics of Egyptian songs, we can find songs that describe feelings of pilgrims and their family or relatives. First, they are deepened with grief because it is a farewell song sung when one is parting with a family member who is about to depart on an arduous journey. On the other hand, the song which greets a pilgrim who returned safely from the pilgrimage is filled with happiness and joy. Also, another characteristic of the songs of pilgrimage 
are that they are not accompanied by instruments. The lyrics of the songs generally tell the pilgrim's expectation of visiting the Prophet and either describe the pilgrimage or the preparation for the pilgrimage, such as the pilgrim asking his relatives to take care of his children after he leaves, and so on.

"yāwalad baladi.. al wadād.. al wadād.../ wa yāwalad baladi mābaqi illāsafar./

wa 'aḥmil bzādi... kuluhu fi ḥubbi alnabi..

yāwalad baladi mābaqi illāsafar./

wa 'ạ̣mil bzādi... kuluhu fi ḥubbi alnabi..."

(Village boy...the one whom I love... the one whom I love..../ and village boy ...I have nothing left but to travel.../ and I carry my things... all of this is for the love of the Prophet...

O... village boy...I have nothing left but to travel.../

and I carry my things...all of this is for the love of the Prophet...)"

Religious views of Muslims can be found when the pilgrim announces to the village boy of his pilgrimage to the Holy Land, and that all things will be done accordingly to the Prophet's will. When departing for the pilgrimage to the Holy Land, songs are sung by the relatives and families together. One of these songs is the following.

" hạājjuna yāhājjuna../hājjuna yāhājjuna...

zurta wa jita yāhājjuna../ yāhājjuna yāhājjuna... yāsālima salamihim../ yāsālima salamihim..

rahu wa juna bisalamah/ yāsālima salamihim.. yāzāir almadinah yāḥājjuna.../ ḥājjuna...yāḥājjuna... yawm ma tajina yāḥājjuna.../ ḥājjuna..yāḥājjuna... yāsālima salamihim../ yāsālima salamihim.. 
rahu wa juna bisalamah/ yāsālima salamihim..

yāzāir almadinah yāḥājjuna.../ ḥājjuna...yāḥājjuna... yawm ma tajina yāḥājjuna.../ ḥājjuna...yāḥājjuna...

(Our pilgrim... our pilgrim... /

You visited (the Holy Land) and came back... Thou pilgrim/

Our pilgrim., thou who has returned safely.. /

Thou who has safely returned... they have gone to...

And has come back safely to us again./

Visitor of the city... Our pilgrim ...Our pilgrim/

Someday you will come back to us...

Our pilgrim... / Our pilgrim...

Thou who has safely returned... they have gone to...

And has come back safely to us again../

Visitor of the city... Our pilgrim ...Our pilgrim/

Someday you will come back to us...

Our pilgrim... / Our pilgrim...Our pilgrim...)"

This song, sung to a pilgrim leaving on a pilgrimage expresses the faith that obedience and submission to Allah can be shown through the endurance of hardship of this sacred ritual, even though the path to the pilgrimage is perilous. In addition, a family's expectation that the pilgrim returns safely from the pilgrimage, fulfilling his sacred duty as a Muslim, is expressed appropriately.

"yāḥājj yawm essalāmah.. 'abyad min laban el halīb..

wa 'abyad min laban el halīb...yāḥājj yawm lrujjū'

wa 'ddini 'aqūlak.. yawm essalāmah maktūbah lak 
'inda nnabi.. anfaqt mālak... w ḥajjayt w raja' t...wa hajjait w raja' t l'iyālak wa zurta wa' adta farhān...

yāhāiaj yawm essalāmah.. 'abyad min laban el halīb..

wa 'abyad min laban el halīb.. yāḥājj yawm Irujjū'

wa 'ddini 'aqūlak.. yawm essalāmah maktūbah lak

'inda nnabi.. anfaqt mālak... w hajjayt w raja' t..wa hajjait w raja' t 1'iyālak

wa zurta wa' adta farhān..."

(Oh pilgrim.. Day of safety... white like fresh milk...

And white like a fresh milk... Oh pilgrim... Day of Return...

As I told you... Day of safety... It's written for you...

For the prophet, you spent your money... and you traveled for the pilgrimage

And you returned to your family... and you traveled for the pilgrimage And you returned to your family... and you visited (the Holy Land)

And you promised pleasurably...

Oh pilgrim.. Day of safety... white like fresh milk...

And white like a fresh milk... Oh pilgrim... Day of Return...

As I told you... Day of safety... It's written for you...

For the prophet, you spent your money... and you traveled for the pilgrimage

And you returned to your family... and you traveled for the pilgrimage And you returned to your family... and you visited (the Holy Land)

And you promised pleasurably...)" 
In this song, we can find the mood of delight and happiness sung to a pilgrim returned to home after finishing a holly pilgrimage, unlike before leaving for the pilgrimage feelings of sadness and worry. It expresses feelings of pride and euphoria about the pilgrim came up with the obligations of the pilgrimage after the completion of the schedule of a long journey that is obligation to practice once in a lifetime as a Muslim.

\subsection{Belief in fate}

The foundation of the Islamic religion is faith (Tman) and practice ("Amal). Faith is divided into six articles which are to be believed in. Those six articles of faith are the following: one and only God, angels, the Koran, prophets, the afterlife, and fate. Among them, fatalism is a doctrine believed by all Muslims that all human actions and world events in the past, present, and the future are predetermined by fate. This is named 'Qadar' by Muslims that is the concept of divine destiny in Islam. It is one of the six articles of faith, along with Belief in the Oneness of Allah, the Revealed Books, the Prophets of Islam, the Day of Resurrection and Angels. This concept has also been mentioned in the Koran as Allah's "Decree". Qadar is one of the aspects of aqidah. Some Muslims believe that the divine destiny is when God wrote down in the Preserved Tablet (alLawhal-Maḥfūz) all that has happened and will happen, which will come to pass as written. According to this belief, a person's action is not caused by what is written in the Preserved Tablet but, rather, the action is written in the Preserved Tablet because God already knows all occurrences without the restrictions of time. The phrase reflects a Muslim doctrine that Allah has measured out the span of every person's life, their lot of good or ill fortune, and the Suits of their efforts. When referring to the future, Muslims frequently qualify any predictions of what will come to pass with the phrase" In sha' Allah", Arabic for "If God willed." The phrase recognizes that human 
knowledge of the future is limited, and that all that may or may not come to pass is under the control and knowledge of God.

Motifs that appear in Egyptian song lyrics contain the Egyptian's belief in fate or fatalism. The belief is that everyone is born with a predetermined fate and that this should be accepted as his destiny because nothing can be done by the power of humans. This belief is often translated to the expression 'Whatever is written on the forehead, one must carefully see it' (Muhammad Maḥmūd Assayād, 1995:15).

" 'illi inkatab 'ale jaben lazim tashūfuh al-'ayn..

fa naḥnu fi hayātina tasima quwah kutibat 'ale jabena 'awamer labudde leha min naffadh

we lesa 'amamna 'ille 'an naqif hiiyaluha mektu fe l'ayde

we 'an nehni laha ru'usna msteslimia..

'illi inkatab 'ale jaben lazim tashūfuh al-'ayn,, fa nahnu fi hayātina tasima quwah kutibat 'ale jabena... we 'an nehni laha ru'usna msteslimia.."

(Whatever is written on the forehead.... The eye must see it...

' In our life... a kind of force written on the forehead will lead us...

Besides, it is God's will to follow... accept it with both hands open...

We are forced to accept by bowing...

Whatever is written on the forehead.... The eye must see it...

In our life... a kind of force written on the forehead will lead us ...

We are forced to accept by bowing...)"

The fatalism mentioned in this song and the belief in fate is a result of the Egyptian people's long history of difficulties and hardships. The big and small events throughout their long and winding history, poverty and sickness, and 
other adversities were overcome through singing songs that consoled the people. As a result, Egyptians came to believe that the key to happiness is to endure the hardships by accepting it as their fate.

"aşşabr tayb wlaw kāna murr naşr lah we'illi 'akl ḥelw aw kullu murr yaşur lah wajib 'alayna Iihukm allah nasbur Iah., w şbr 'uqbahu faraj 'aḥla min I $\min$ 'ad...

aşşabr tayb wlaw kāna murr naşr lah we'illi 'akl ḥelw.... w şbr'uqbahu faraj 'ạ̣la min I min'ad..."

(Patience is good, whatever pain we may overcame,

It will bear sweet efforts... Whatever pain we may overcame...

God will be the judge... after endurance follows sweet happiness....

Patience is good, whatever pain we may overcame... and after endurance follows sweet happiness...)"

The belief that someday one will be compensated with tranquil rest after one has endured endless hardship can be read in the song above. According to Muḥammad Maḥmūd Assayād, this belief in fatalism has influenced the Egyptians in to accepting life's happiness or hardships as they come and therefore the cause of absence of ideals and reduction of social creativity in the Egyptian society (Muḥammad Maḥmūd Assayād, 1995:16).

\section{Conclusion}

Until now, we examined the religious consciousness of Egyptian people seen through the lyrics of the traditional folk songs based on the expression of sacredness that was categorized by topic. First, the paper introduced Egyptian folk songs and then examined the lyrics of these songs with the representation of the expressions of sacredness in the Egyptian traditional folk song and 
categorized them according to the themes and then examined the religious consciousness of the Egyptian people based on these themes.

We can say that the Islamic religion has had a profound impact on Egyptian music overall, and religious factors appear in all musical expressions. Lyrics rooted from religion can also be found, such as calling out, 'Allah', '0 Lord' asking for redemption. The Egyptian way of thinking in steering closer to Allah can be seen through religious motifs such as the authority and Providence of the Almighty God, man's absolute obedience to God, appraisal of the prophets and saints, Islamic fatalism, and Islamic duty of pilgrimage and prayer. Islam has been at the center of the Middle Eastern civilization, impacting the Egyptian's way of thinking and structural development of the common people since the 7th century. And it can be said that to this day, it still comprises an insurmountable portion of popular culture, thereby providing understanding of sacredness. The firm belief in the One and Only God, a believer's ideal virtues, compliance to the Islamic doctrine, and such are established in the Arab people's way of thinking as an element of holiness.

The way of thinking about sacredness implied in the Egyptian songs emphasize the Islamic doctrine and absolute obedience to the Almighty God, keeping the faith in the Prophet, goodness and virtue in a personal relationship, and the importance of faith. Comprising a vast majority of the important part of the Egyptian mass culture, research on the lyrics of folk songs provides an opportunity to take a look into the inner level of their society; and furthermore, they are also considered to help assist in understanding the Arab culture on a higher level. 


\section{References}

Abd al-Man'am, Safā'(2004), Aghānī wa Al'āb Sha'bīyyah lil- 'Atfāl, Cairo; al- Sharikah aI-'Ālamiyyah lil-ţibā 'ah.

Abū Zayd, 'Aḥmad (1972), Dirāsāt Fīal-Fulklūr, Miṣr: Maṭba'ah Dār Nashr al- Thaqāfah.

Ahmad Amīn(2003), Qāmūs al-Ādāt wa al-Taqālīd wa al-Ta'ābīr alMișrīyyah, Cairo: Maṭba'at Lajnat al-Ta'līf wa al-Tarjamah wa alNashr.

Aḥmad, Taymūr Bik (1963), al-Musīqā wa al-Ghinā' inda aUArab, Cairo: Dār Ittiḥād lil-țibā'ah.

Al-Kaysi, Marwan Ibrahim (1986), Morals and Manners in Islam, The Islamic Foundation.

al-Kūlī, Samhah(1992), al-Qawmiyyah fi Mūsīqā al-Qarn al- Ishrīn, 'Ālam al- Ma'rifah.

Amnon Shiloah(1995), Music in the World of Islam, Detroit: Wayne State Univ. Press.

Aziz al-Shawan(2005), al- Musīqā liljamī, Cairo: Maktabat al-'Usrah.

Bū Dinah Muhammad(1999), al- Mawwāl fi al-Ghina' al-'Arabi, Tunis: alSharikah al-Tunisiyyah linnashr.

Bahījah, Rasīd ( 1967), Aghān wa Al'āb Sha‘bīyyah Miṣrīyyah» Cairo: Ālam al- Kutub.

Choi, Young Kil (1985), Islamic StandardNorms. Seoul: Myongji University Press.

Choi, Young Kil (1995), Korean Translation of the Glorious Qur'an. Medina: King Fahd Glorious Qur'an Printing Complex. 
Danielson, Virginia Louise ( 1997), The Voice of Egypt: Umm Kulthum, Arabic Song, and Egyptian Society in the Twentieth Century, Chicago: University of Chicago Press.

El-Said Badawi \& Martin Hinds(1986), A Dictionary of Egyptian Arabic, Arabic- English, Beirut: Librairie Du Liban.

Habib Hassan Touma(2003), The Music of the Arabs, London: Amadeus Press.

Hasan M. El-Shamy(1995), Folk Traditions of the Arab World: A Guide to Motif Classification, vol. 1-2, Bloomington and Indianapolis: Indiana University Press.

Kamāl al-Nāji(1992), Turāth al-Ghinā' al- Arabi, Dār al- Shurūq.

Gennep, Arnold van (2000), (Les) Rites de passage, trans. Kyung Soo Jeon. Seoul: Eulyoo Book Publishing.

Lee, Hwee Soo (1995), "Part 2 Area Studies: The Rites of Passage in Islamic Society”. Cross-Cultural Studies, 2: 169-201.

Maḥmūd Assayād Muḥammad(1995), "Nafsiyyatu al -Sha‘b al- Miṣrīmin Aghānihi", aUFunūnal-sha'biyyah, No. 48., Cairo: al-Hay’ah al-Mișriyyah aI-‘'̄Ammah lil-kitāb.

Mursi Aḥmad (1970) al-Ughniyyah al- Sha'biyyah, Cairo: al-Maktabah alThaqāfiyyah.

Yun Eun-Kyeong(2006), 'A Study on Egyptian Folk Song - Focused on Work Song'. Mediterranean Review, 8(2): 115-45.

Yunis, Abd al-ḥamīd(1983), Difā' 'an al-Fūlklūr, Cairo: al-Hay'ah alMiṣriyyah al-Āmmah lil-kitāb. 